\title{
Nanostructured and Boron-Doped Diamond as an Electrocatalyst for Nitrogen Fixation
}

Bin Liu, ${ }^{1,2}$ Yongping Zheng, ${ }^{3}$ Hui-Qing Peng, ${ }^{1}$ Bifa $\mathrm{Ji},{ }^{3}$ Yang Yang, ${ }^{* 3}$ Yongbing Tang, ${ }^{* 3}$

Chun-Sing Lee, ${ }^{*, 4}$ Wenjun Zhang*,1,5

${ }^{1}$ Center of Super-Diamond and Advanced Films (COSDAF) \& Department of Materials

Science and Engineering, City University of Hong Kong, Tat Chee Avenue, Kowloon, Hong Kong, China

${ }^{2}$ State Key Laboratory of Chemical Resource Engineering, Beijing University of Chemical Technology, Beijing 100029, China

${ }^{3}$ Functional Thin Films Research Center, Shenzhen Institutes of Advanced Technology, Chinese Academy of Sciences, Shenzhen 518055, China

${ }^{4}$ Center of Super-Diamond and Advanced Films (COSDAF) \& Department of Chemistry, City University of Hong Kong, Tat Chee Avenue, Kowloon, Hong Kong, China ${ }^{5}$ City University of Hong Kong Shenzhen Research Institute, Shenzhen 518057, China *Correspondence to: E-mail: yang.yang1@siat.ac.cn (Y.Y.); tangyb@siat.ac.cn (Y.T.); apcslee@cityu.edu.hk (C.S.L); apwjzh@cityu.edu.hk (W.Z) 


\section{EXPERIMENTAL SECTION}

Materials synthesis. The boron-doped and nanostructured diamond electrodes in the present study were prepared by hot-filament chemical vapor deposition (HFCVD) and subsequent bias-assisted reactive ion etching (RIE). Before deposition, the titanium meshes were ultrasonically cleaned in acetone, ethanol, and deionized water in sequence for $5 \mathrm{~min}$ each. Afterwards, the titanium meshes were sonicated for 30 min in solution of $\mathrm{H}_{2} \mathrm{SO}_{4}: \mathrm{H}_{2} \mathrm{O}_{2}=1: 5$, then ultrasonically seeded for $60 \mathrm{~min}$ in a suspension of diamond powder with a grain size of $5 \mathrm{~nm}$ to obtain a high nucleation density, followed by rinsing in ethanol and drying with $\mathrm{N}_{2}$.

During the growth of BND films by HFCVD, the filament temperature was maintained at $2400 \pm 100{ }^{\circ} \mathrm{C}$, and the distance between the filament and the substrate was kept at $20 \mathrm{~mm}$. The deposition was performed in $\mathrm{CH}_{4}, \mathrm{H}_{2}$ and $\mathrm{Ar}$ gas mixture with trimethylborane (TMB, diluted by $\mathrm{H}_{2}$ to $\left.1000 \mathrm{ppm}\right)$ as the boron doping source. The boron-carbon $(\mathrm{B} / \mathrm{C})$ ratio in the feed gas mixture was adjected from 1000 to $4000 \mathrm{ppm}$ to control the boron content in diamond films. The total gas-flow rate and pressure were $500 \mathrm{sccm}$ and $1.5 \mathrm{kPa}$, respectively. Following the HFCVD process, the BND films were subjected to bias-assisted RIE using ECR microwave plasma to obtain a nanostructured surface. The RIE conditions were as follows: gas mixture of TMB (diluted by $\mathrm{H}_{2}$ to $1000 \mathrm{ppm}$ ) : $\mathrm{Ar}=9 \mathrm{sccm}: 6 \mathrm{sccm}$, pressure 7 mTorr; and the etching duration $\sim 1$ hour. A negative substrate bias was applied during RIE to manipulate the configuration of surface nanostructures, e.g., nanocone arrays ( $-55 \mathrm{~V})$ vs. nanopillar arrays $(-150 \mathrm{~V})$. Further details of the RIE processes could be found elsewhere ${ }^{1-3}$.

Materials characterization. The morphologies of the samples were observed by TEM and HRTEM on JEM 2100F operated at $200 \mathrm{kV}$. SEM images were obtained on a Philips XL30 FEG at an accelerating voltage of $15 \mathrm{kV}$. XPS measurements were performed using an ESCALAB 220i-XL spectrophotometer with Al-K $\mathrm{K}_{\alpha}$ radiation. Raman spectra were collected on Renishaw Raman spectrometer. The UV-Vis. absorption spectra were measured on 
SHIMADZU UV-1700 UV-Vis spectrophotometer.

Electrocatalytic nitrogen reduction measurements. The NRR experiments were carried out in a two-compartment cell separated by Nafion 211 membrane under ambient condition. The membrane was protonated by boiling in deionized water for $1 \mathrm{~h}$ and then treating in $\mathrm{H}_{2} \mathrm{O}_{2}$ $(5 \%)$ aqueous solution at $80{ }^{\circ} \mathrm{C}$ for another $1 \mathrm{~h}$. Afterwards, the membrane was treated in 0.5 $\mathrm{M} \mathrm{H}_{2} \mathrm{SO}_{4}$ at $80{ }^{\circ} \mathrm{C}$ for $3 \mathrm{~h}$ and subsequently immersed in water for $6 \mathrm{~h}$. The electrochemical measurements were undertaken using an electrochemical workstation (CHI 660E). The prepared electrode (the geometric area of the electrode is $1.5 \mathrm{~cm}^{2}$ ), saturated calomel electrode (SCE), and graphite rod were chosen as the working electrode, reference electrode, and counter electrode, respectively. The potentials were referenced to the reversible hydrogen electrode according to the following equation: $\mathrm{E}(\mathrm{vs}$. RHE) $=\mathrm{E}(\mathrm{vs}$. SCE) $+0.256 \mathrm{~V}+$ $0.05916 \times \mathrm{pH}$. For electrochemical $\mathrm{N}_{2}$ reduction, chrono-amperometry tests were conducted in $\mathrm{N}_{2}$-saturated $0.05 \mathrm{M} \mathrm{H}_{2} \mathrm{SO}_{4}$ solution containing $0.2 \mathrm{M} \mathrm{Li}_{2} \mathrm{SO}_{4}$ (the electrolyte was purged with ultra-high purity $\mathrm{N}_{2}(99.999 \%)$ for $30 \mathrm{~min}$ before the measurement). To eliminate the interference of trace amounts of $\mathrm{NO}_{3}{ }^{-}$or/and $\mathrm{NO}_{2}{ }^{-}$in $\mathrm{Li}_{2} \mathrm{SO}_{4}, \mathrm{Li}_{2} \mathrm{SO}_{4}$ was heated at $800{ }^{\circ} \mathrm{C}$ for $4 \mathrm{~h}$ under Ar atmosphere in a tube furnace and was naturally cooled down to room temperature ${ }^{4}$. The volume of the electrolyte in the anode and cathode chamber is $30 \mathrm{~mL}$ for each. Before the electrocatalytic NRR experiments, argon was purged to the cathodic cell to remove impurity gas and then the gases to be tested were purged to the cell for $30 \mathrm{~min}$. The

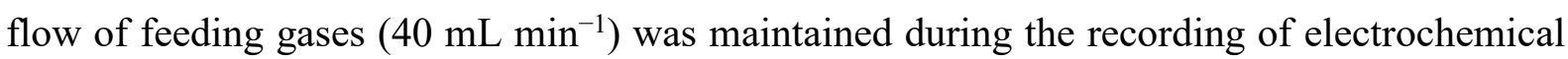
data. ${ }^{14} \mathrm{~N}_{2}$ was supplied by Hinde HKO LTD. The gas composition: ${ }^{14} \mathrm{~N}_{2}\left(\geq 99.999 \%\right.$ (vol)), $\mathrm{O}_{2}$ ( $\leq 5 \mathrm{ppm}$ (vol)), $\mathrm{H}_{2} \mathrm{O}(\leq 3 \mathrm{ppm}(\mathrm{vol}))$, and $\mathrm{CH}_{4}(\leq 1 \mathrm{ppm}(\mathrm{vol}))$. To eliminate the effect of potential nitrogen-based impurities, before tests, ${ }^{14} \mathrm{~N}_{2}$ (or ${ }^{15} \mathrm{~N}_{2}$ ) was pre-purified through sequentially following into $0.1 \mathrm{M} \mathrm{KOH}$, and $0.05 \mathrm{M} \mathrm{H}_{2} \mathrm{SO}_{4}{ }^{5-7}$.

Quantification of ammonia. The concentration of $\mathrm{NH}_{3}$ produced during NRR process was 
spectrophotometrically detected by the indophenol blue method. Specifically, $2 \mathrm{~mL}$ electrolyte was taken from the cathodic chamber, and then $2 \mathrm{~mL}$ of $1 \mathrm{M} \mathrm{NaOH}$ solution containing 5\% salicylic acid and 5\% sodium citrate was added into the electrolyte, followed by adding $1 \mathrm{~mL}$ of $0.05 \mathrm{M} \mathrm{NaClO}$ and $0.2 \mathrm{~mL}$ of $1 \% \mathrm{C}_{5} \mathrm{FeN}_{6} \mathrm{Na}_{2} \mathrm{O} \cdot 2 \mathrm{H}_{2} \mathrm{O}$ into the above solution. After keeping for $2 \mathrm{~h}$, the UV-Vis absorption spectrum was measured, and the absorbance was estimated at a wavelength of $655 \mathrm{~nm}$. The concentration-absorbance curves were calibrated using standard $\mathrm{NH}_{3}$ solution with varying concentrations.

Quantification of hydrazine. The possible $\mathrm{N}_{2} \mathrm{H}_{4}$ product in the electrolyte was estimated by the method of Watt and Chrisp. A mixed solution of $5.99 \mathrm{~g} \mathrm{C}_{9} \mathrm{H}_{11} \mathrm{NO}, 30 \mathrm{~mL} \mathrm{HCl}$, and 300 $\mathrm{mL}$ ethanol was used as sensitive chromogenic reagent. The absorbance of $\mathrm{N}_{2} \mathrm{H}_{4}$ after mixing with the chromogenic reagent in the resulting electrolyte was estimated at $457 \mathrm{~nm}$.

Calculation of $\mathrm{NH}_{3}$ yield and Faradaic efficiency. The $\mathrm{NH}_{3}$ yield rate was calculated through the following equation: $r\left(\mathrm{NH}_{3}\right)=(\mathrm{c} \times \mathrm{V}) /(\mathrm{t} \times \mathrm{S})$, where $\mathrm{c}$ is the measured $\mathrm{NH}_{3}$ concentration, $\mathrm{V}$ is the volume of the electrolyte, $\mathrm{t}$ is the electrochemical reaction time, and $\mathrm{S}$ is the geometric area of the electrode. The Faradaic efficiency was calculated as follows: FE $=3 \mathrm{~F} \times \mathrm{c} \times \mathrm{V} /(17 \times \mathrm{Q})$, where $\mathrm{F}$ is the Faraday constant, $\mathrm{c}$ is the $\mathrm{NH}_{3}$ concentration, $\mathrm{V}$ is the volume of the electrolyte, and Q is the quantity of applied electricity.

${ }^{15} \mathbf{N}_{2}$ and ${ }^{14} \mathbf{N}_{2}$ 1H-NMR measurements. ${ }^{15} \mathrm{~N}_{2}$ was used as feeding gas to verify the exact nitrogen source for NRR experiments. ${ }^{15} \mathrm{~N}_{2}$ was purchased from Wuhan Newradar Special Gas Co., LTD. with the purity of $>99 \%$ (vol). The impurities in the ${ }^{15} \mathrm{~N}_{2}$ include $\mathrm{O}_{2}, \mathrm{H}_{2} \mathrm{O}$ and $\mathrm{CO}_{2}$. A low-velocity gas flow of approximately $5 \mathrm{~mL} \mathrm{~min}^{-1}$ for the labelling experiment was adopted due to the limited supply and expense of ${ }^{15} \mathrm{~N}_{2}$. After electrolysis at $-0.7 \mathrm{~V}$ vs. RHE for $1 \mathrm{~h}, 30 \mathrm{~mL}$ of the electrolyte was taken out and then concentrated to $3 \mathrm{~mL}$ by reduced pressure distillation. Afterwards, $0.95 \mathrm{~mL}$ of the resulting solution was mixed with $0.05 \mathrm{~mL}$ D6-DMSO for 1H-NMR measurement. 
Quantification of ${ }^{15} \mathrm{NH}_{4}{ }^{+}$and ${ }^{14} \mathrm{NH}_{4}{ }^{+}$via $1 \mathrm{H}-\mathrm{NMR}$. The concentration of ${ }^{15} \mathrm{NH}_{4}{ }^{+}$or ${ }^{14} \mathrm{NH}_{4}{ }^{+}$ was calculated by $1 \mathrm{H}-\mathrm{NMR}$ according to the previously reported methods ${ }^{6,8}$. The concentration-integral area curve of ${ }^{15} \mathrm{NH}_{4}{ }^{+}$or ${ }^{14} \mathrm{NH}_{4}{ }^{+}$was calibrated using a series of standard $\left({ }^{15} \mathrm{NH}_{4}\right)_{2} \mathrm{SO}_{4}$ or $\left({ }^{14} \mathrm{NH}_{4}\right)_{2} \mathrm{SO}_{4}$ solutions with different concentrations, and employing a known amount of D6-DMSO as an internal standard.

Density functional theory computation. The geometries and free energies in this work were calculated using DFT method implemented in the Vienna ab initio simulation package $(\mathrm{VASP})^{9}$. The projector-augmented wave method (PAW) ${ }^{10}$ was adopted to address the rapid oscillations issue of valence wavefunctions near ion cores. The generalized gradient approximation (GGA) with Perdew-Burke-Ernzerhof (PBE) $)^{11}$ function was used to describe the exchange correlation interactions. The cutoff energy was set to be $450 \mathrm{eV}$, and the criteria of convergence for electronic energy and ionic force were $10^{-5} \mathrm{eV}$ and $10^{-2} \mathrm{eV} / \AA$, respectively. The conjugate gradient method is used to minimize the Hellmann-Feynman forces in the ionic relaxations. The Brillouin zone was sampled with a Monkhorst $k$-mesh to keep the reciprocal spacing less than $0.03 \AA^{-1}$. A rectangular (surface vectors of $\left[\begin{array}{lll}1 & 1 & -2\end{array}\right]$ and [ $\left.\left.\begin{array}{lll}1 & -1 & 0\end{array}\right]\right) 2 \times 4$ slab model with $128 \mathrm{C}$ atoms was used to model the diamond (111) surface, a rectangular (surface vectors of [ $\left[\begin{array}{lll}0 & 0 & 1\end{array}\right]$ and $\left.\left[\begin{array}{lll}1 & -1 & 0\end{array}\right]\right) 2 \times 4$ slab model with $112 \mathrm{C}$ atoms was used to model the diamond (110) surface, and a rectangular (surface vectors of [ $\left[\begin{array}{lll}0 & 1 & 1\end{array}\right]$ and $\left[\begin{array}{ll}0 \\ 0\end{array}\right.$ 1 -1]) $3 \times 4$ slab model with $120 \mathrm{C}$ atoms was used to model the diamond (100) surface. The surface areas of diamond (111), (110) and (100) slabs were $89.9 \AA^{2}, 73.3 \AA^{2}, 76.0 \AA^{2}$, respectively. A vacuum layer above $10 \AA$ was used in all surface modeling to avoid periodic slab interaction. The doping concentration of boron in the supercell is below 1 at $\%$. The reaction free energies of proton-coupled electron transfer steps were calculated with respect to standard hydrogen electrode (SHE), i.e., the free energy of $\left(\mathrm{H}^{+}+\mathrm{e}^{-}\right)$couple is equal to the free energy of half of the $\mathrm{H}_{2}$ gas molecule at standard condition. The free energy change of 
each reaction steps can be calculated as follows,

$$
\Delta G=\Delta E+\Delta E \mathrm{ZPE}-T \Delta S
$$

where $\Delta E$ denotes the change of reaction free energy obtained from DFT computation, $\Delta E_{\mathrm{ZPE}}$ and $\Delta S$ denote the changes in zero-point energy and entropy of each reaction steps, which were calculated from the vibrational frequencies of the adsorbed species and gas-phase molecules as previous reports ${ }^{12,13}$; the corresponding entropies of the gas-phase molecules were taken from the NIST database https://janaf.nist.gov/. 


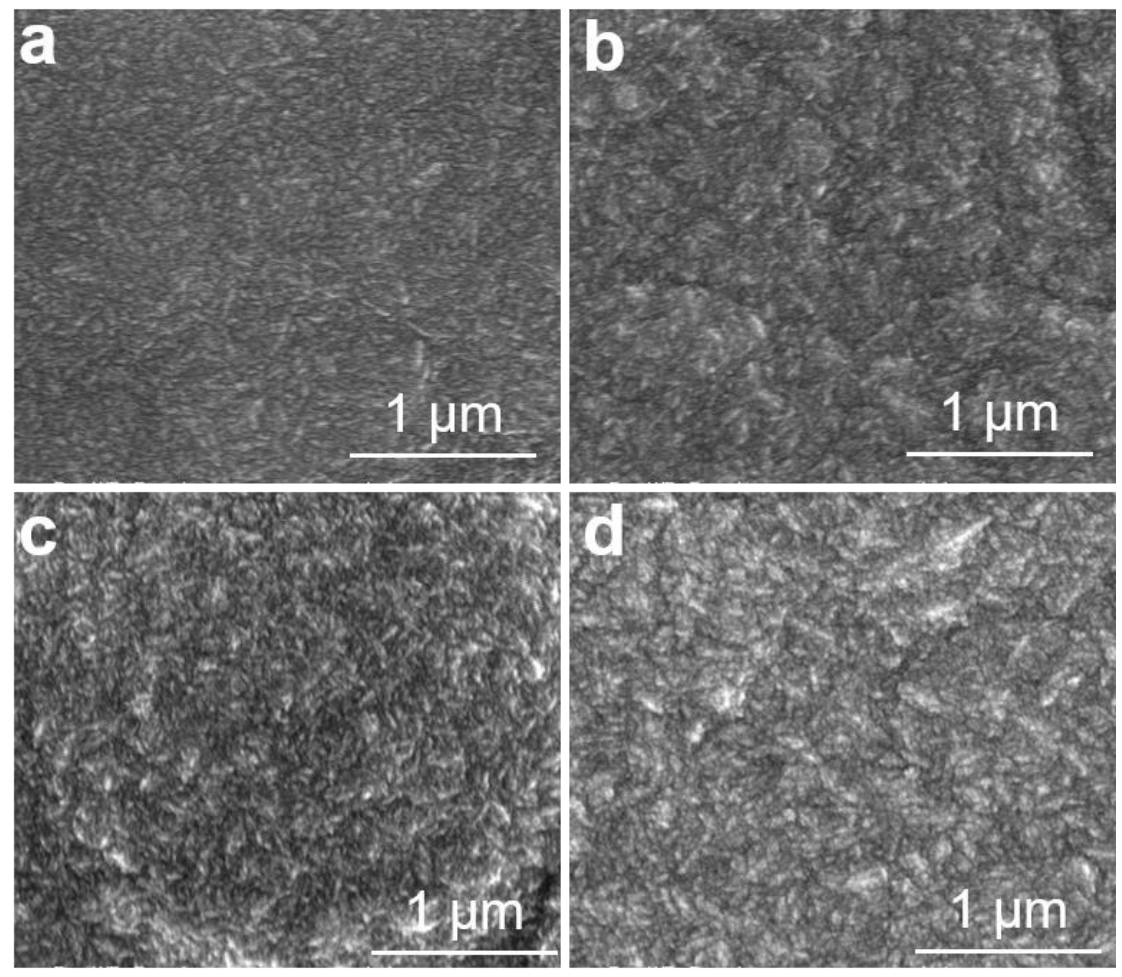

Figure S1. SEM images of BND films with different B doping concentrations. The boron-carbon (B/C) ratios in the feed gas mixture were (a) 0, (b)1000, (c) 3000, and (d) $4000 \mathrm{ppm}$, respectively. 


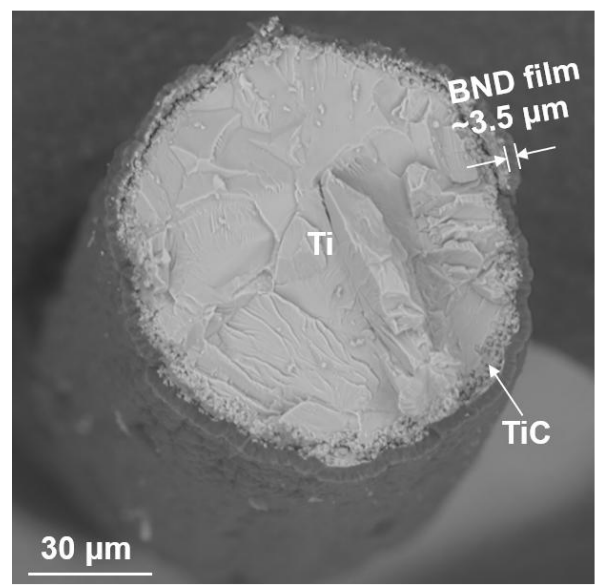

Figure S2. Cross-section SEM view of $\mathrm{BND}_{2} / \mathrm{Ti}$ electrode. 


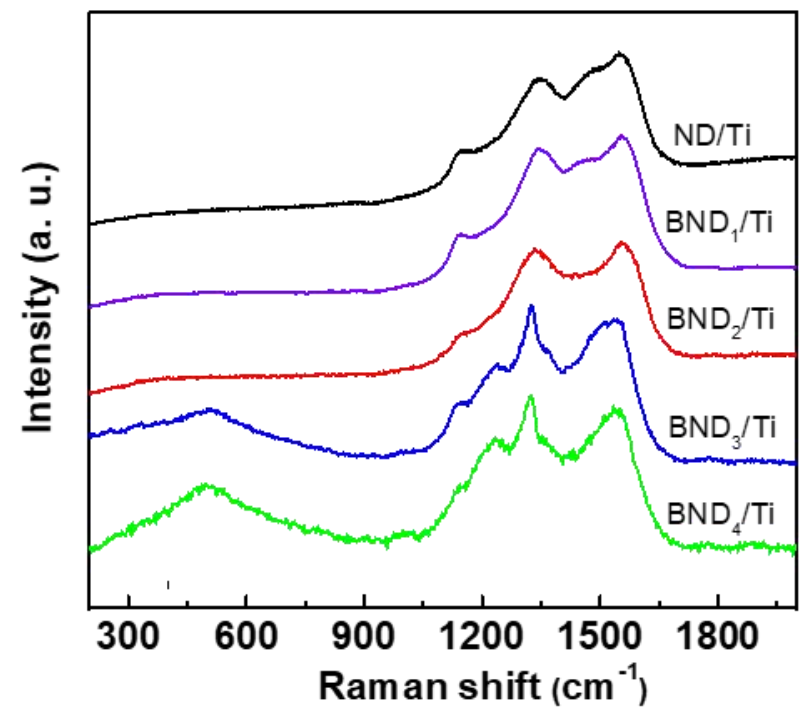

Figure S3. Raman spectra of BND/Ti electrodes with different boron doping levels. The peak located at around $1140 \mathrm{~cm}^{-1}$ is attributed to polyacetylene generated at the grain boundary of nanocrystalline diamond. The broad peaks at 500 and $1225 \mathrm{~cm}^{-1}$ related to locally distorted lattice structure induced by the incorporation of boron appear when the $\mathrm{B} / \mathrm{C}$ ratio increases to $3000 \mathrm{ppm}$ in the feed gas, and the two broad peaks become more intense with the increase of $\mathrm{B} / \mathrm{C}$ ratio in reaction atmosphere. In addition, the peak at around $1332 \mathrm{~cm}^{-1}$ belonging to the triply degenerate zone-center phonon of the $\mathrm{sp}^{3}$ crystalline diamond lattice exhibits a shift towards lower wavenumber upon increasing B content ${ }^{14,15}$. 


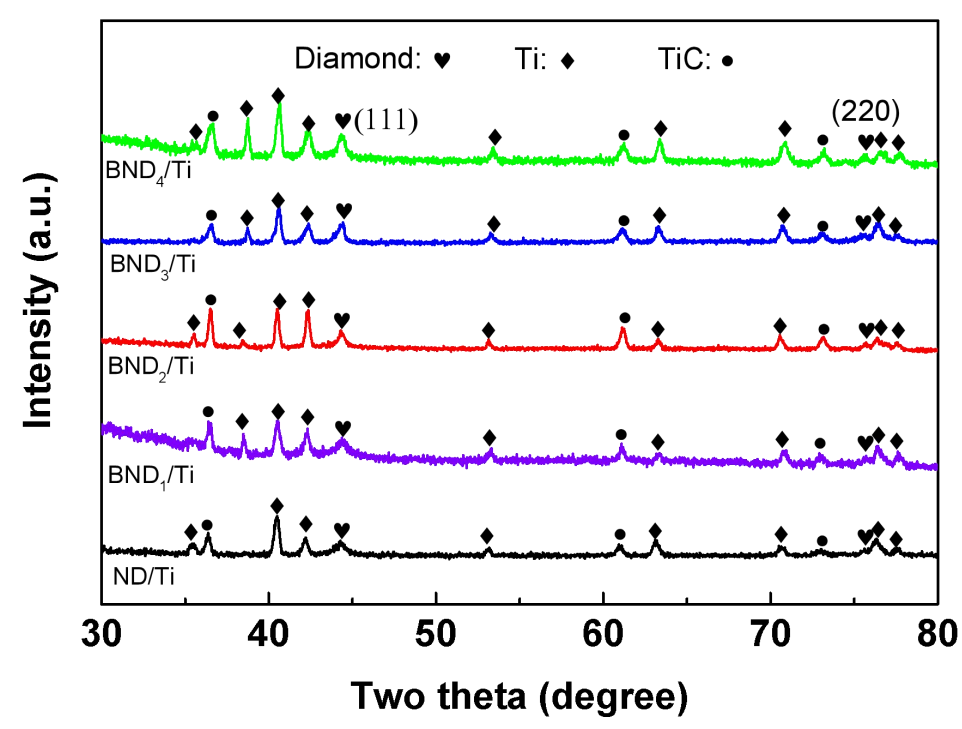

Figure S4. The XRD patterns of nanodiamond films on Ti meshes with different boron doping levels. Besides the peaks from Ti substrates, the peaks at $2 \theta=43.9^{\circ}$ and $75.2^{\circ}$ are assigned to the (111) and (220) diffractions of diamond. In addition, the observation of TiC peaks indicates the formation of $\mathrm{TiC}$ interlayer resulted from the reaction of $\mathrm{Ti}$ with carbon-containing species under diamond deposition conditions. The interfacial TiC layer was completely wrapped by the diamond film, and thus it did not participate in the electrocatalytic reactions. 


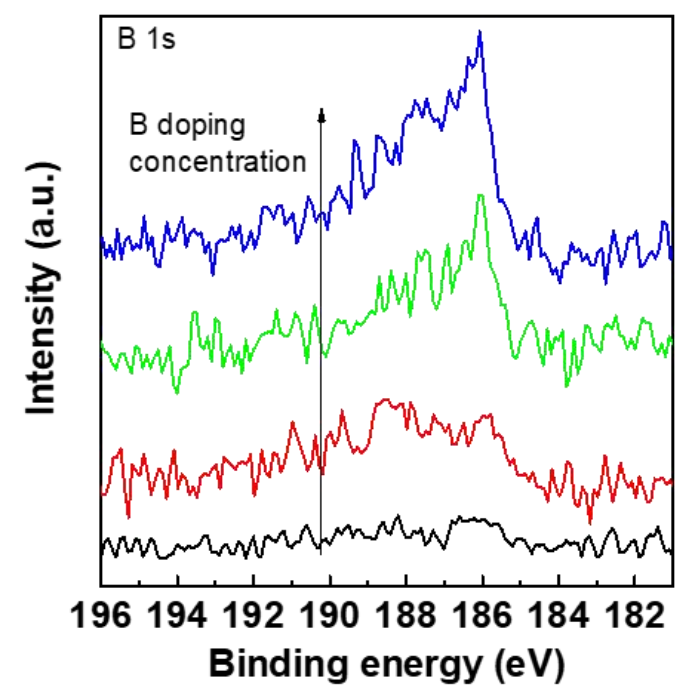

Figure S5. High-resolution B 1s XPS signals of the samples. From bottom to top: $\mathrm{BND}_{1} / \mathrm{Ti}$, $\mathrm{BND}_{2} / \mathrm{Ti}, \mathrm{BND}_{3} / \mathrm{Ti}$, and $\mathrm{BND}_{4} / \mathrm{Ti}$. 


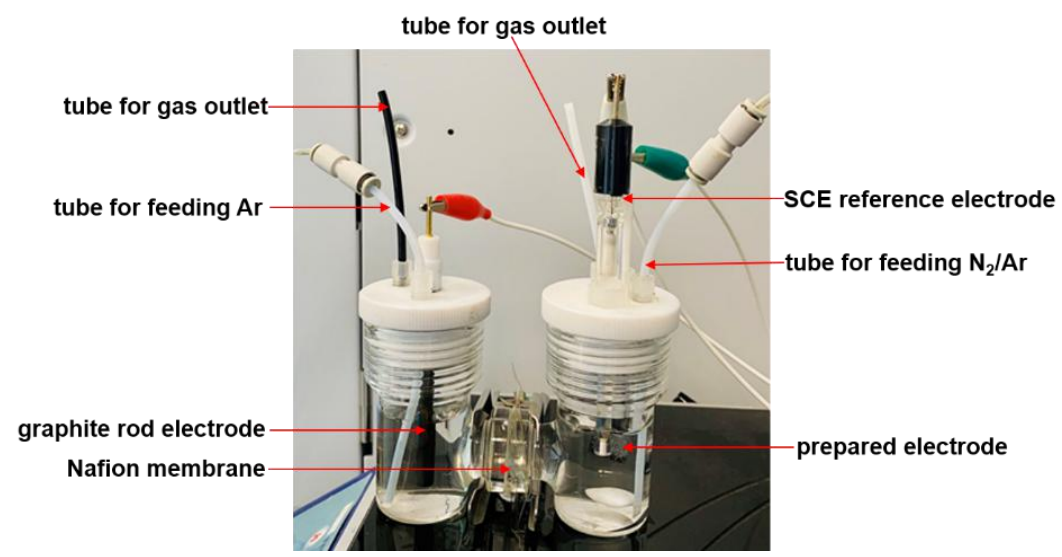

Figure S6. Photo of electrochemical reaction setup for NRR. 

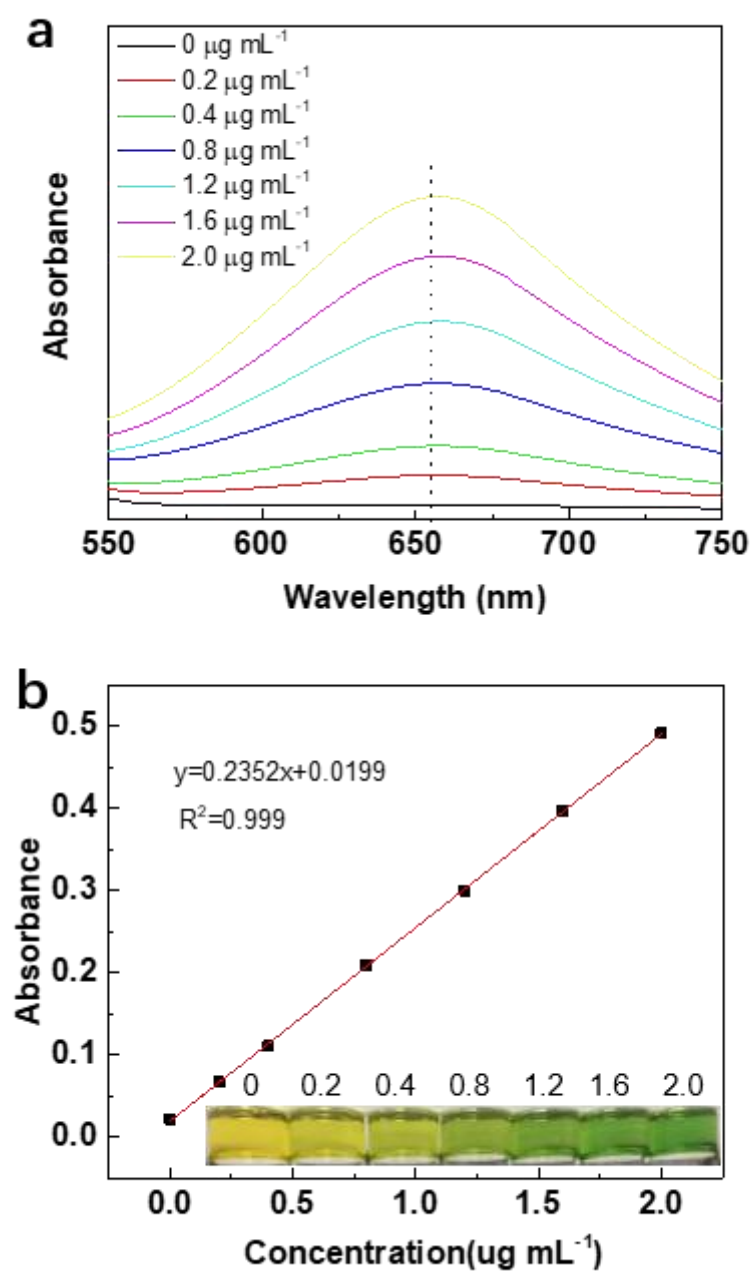

Figure S7. UV-Vis absorption spectra and calibration curve. (a) UV-Vis absorption spectra of indophenol assays with different $\mathrm{NH}_{3}$ concentrations after incubated for $2 \mathrm{~h}$ at room temperature. (b) Calibration curve used for determining $\mathrm{NH}_{3}$ concentration. 

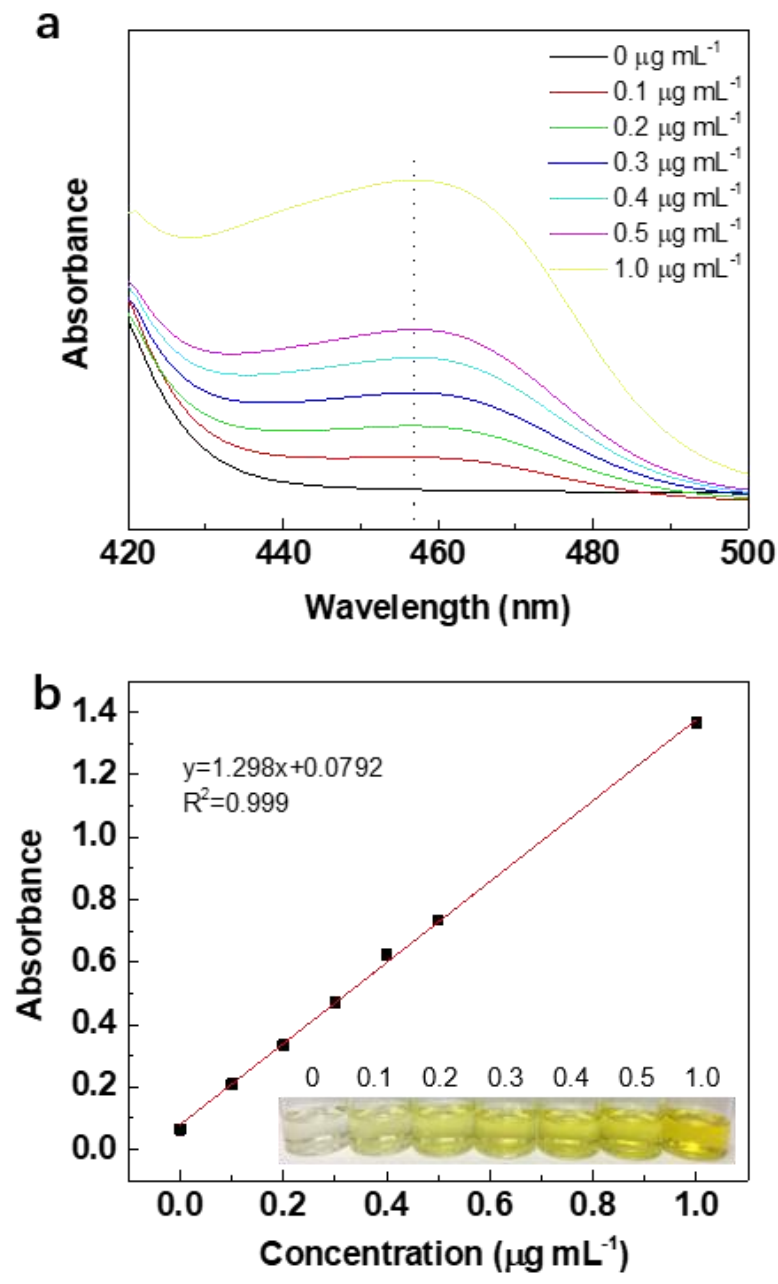

Figure S8. UV-Vis absorption spectra and calibration curve. (a) UV-Vis absorption spectra of solution with different $\mathrm{N}_{2} \mathrm{H}_{4}$ concentrations after incubated for $20 \mathrm{~min}$ at room temperature. (b) Calibration curve used for determining $\mathrm{N}_{2} \mathrm{H}_{4}$ concentration. 


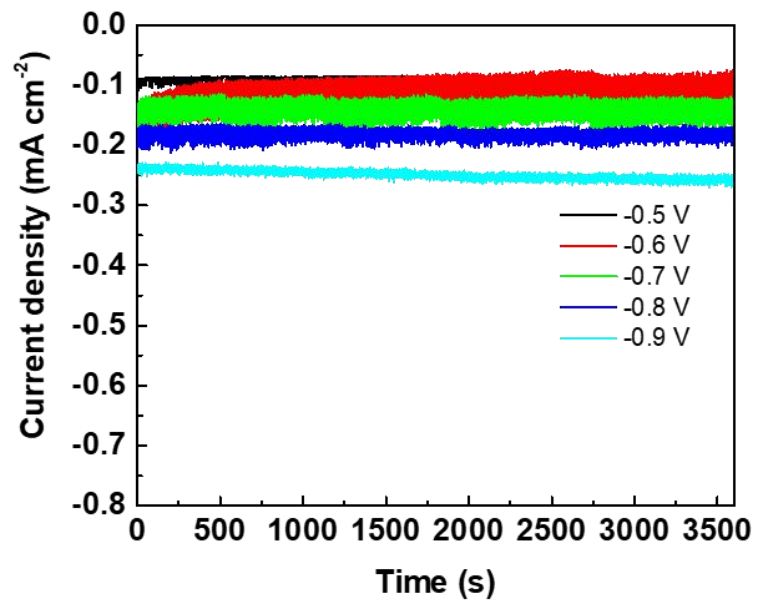

Figure S9. Chrono-amperometry curves. The chrono-amperometry curves of $\mathrm{BND}_{2}-\mathrm{NC} / \mathrm{Ti}$ at various potentials. 


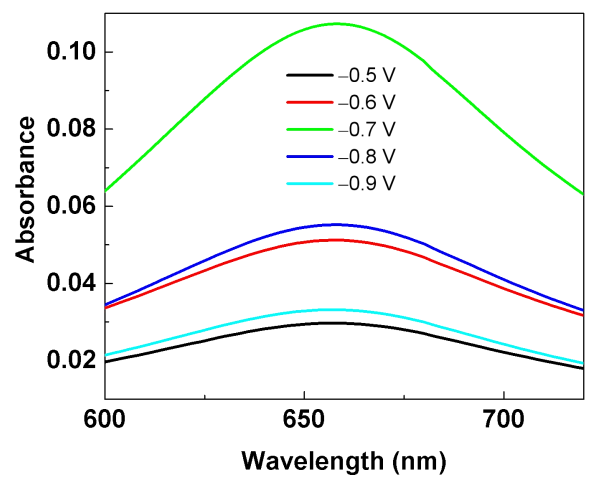

Figure S10. UV-Vis absorption spectra. The UV-vis absorption spectra of the electrolytes stained with indophenol indicator after electrolysis at a series of potentials using $\mathrm{BND}_{2}-\mathrm{NC} / \mathrm{Ti}$ electrode. 


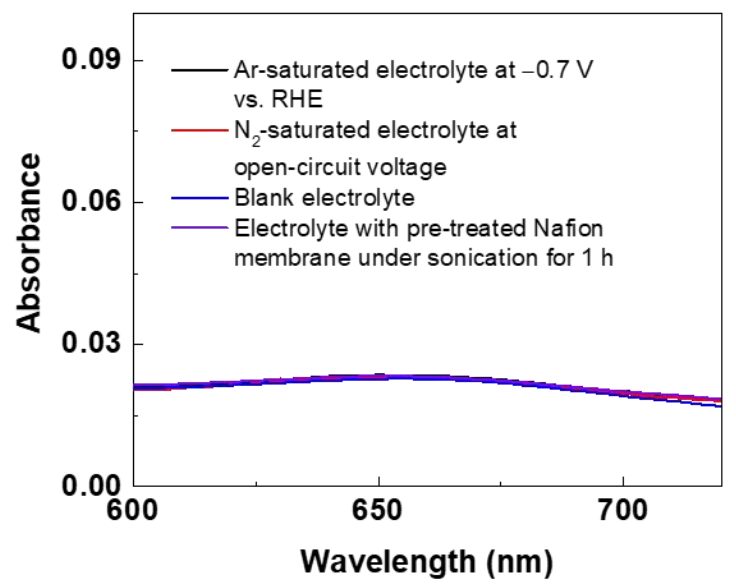

Figure S11. UV-Vis absorption spectra. UV-Vis absorption spectra of the electrolytes obtained under different conditions stained with indophenol indicator. The UV-Vis absorption spectrum of the blank electrolyte stained with indophenol indicator is also presented for reference. 

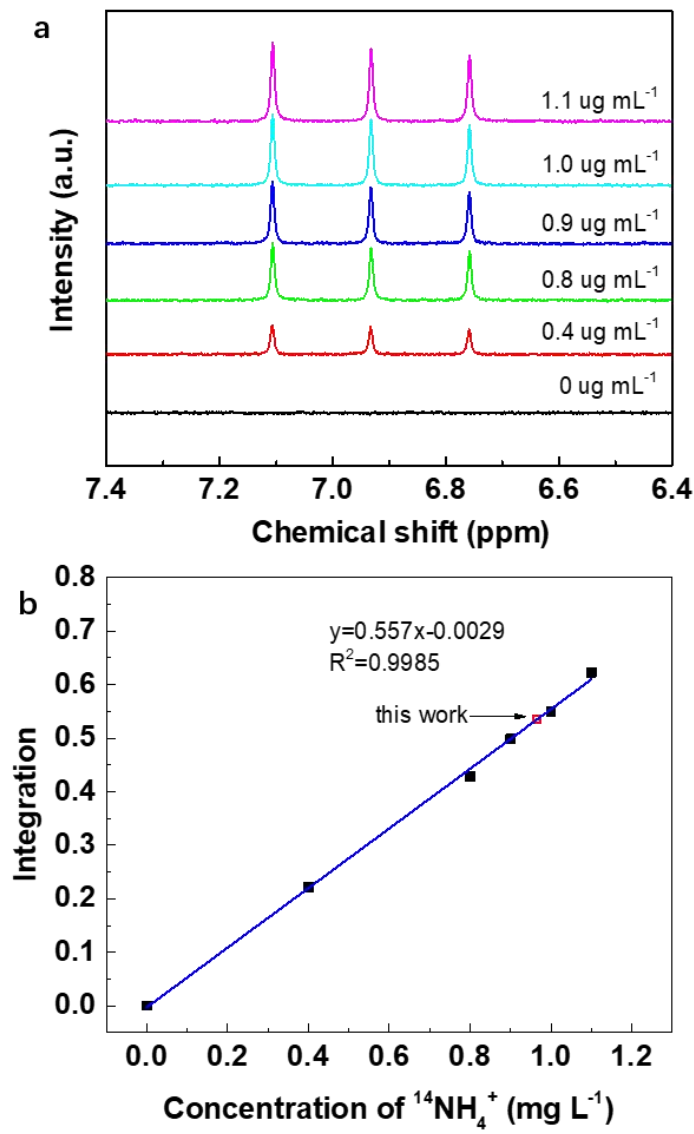

Figure S12. NMR spectra and calibration curve. (a) The 1H-NMR spectra of standard ${ }^{14} \mathrm{NH}_{4}{ }^{+}$with a series of preset concentrations. (b) The calibration curve showing the correlation of ${ }^{14} \mathrm{NH}_{4}{ }^{+}$concentration with the integrated area of the $1 \mathrm{H}-\mathrm{NMR}$ peaks. The calibration curve showed a good linear dependence of the integrated area on ${ }^{14} \mathrm{NH}_{4}{ }^{+}$ concentration $\left(y=0.557 x-0.0029, R^{2}=0.9985\right)$. The red square indicated that the concentration of ${ }^{14} \mathrm{NH}_{4}{ }^{+}$was $0.96 \mathrm{mg} \mathrm{L}^{-1}$ after electrolysis at $-0.7 \mathrm{~V}$ vs. RHE for $1 \mathrm{~h}$ with ${ }^{14} \mathrm{~N}_{2}$ as the feeding gas. 

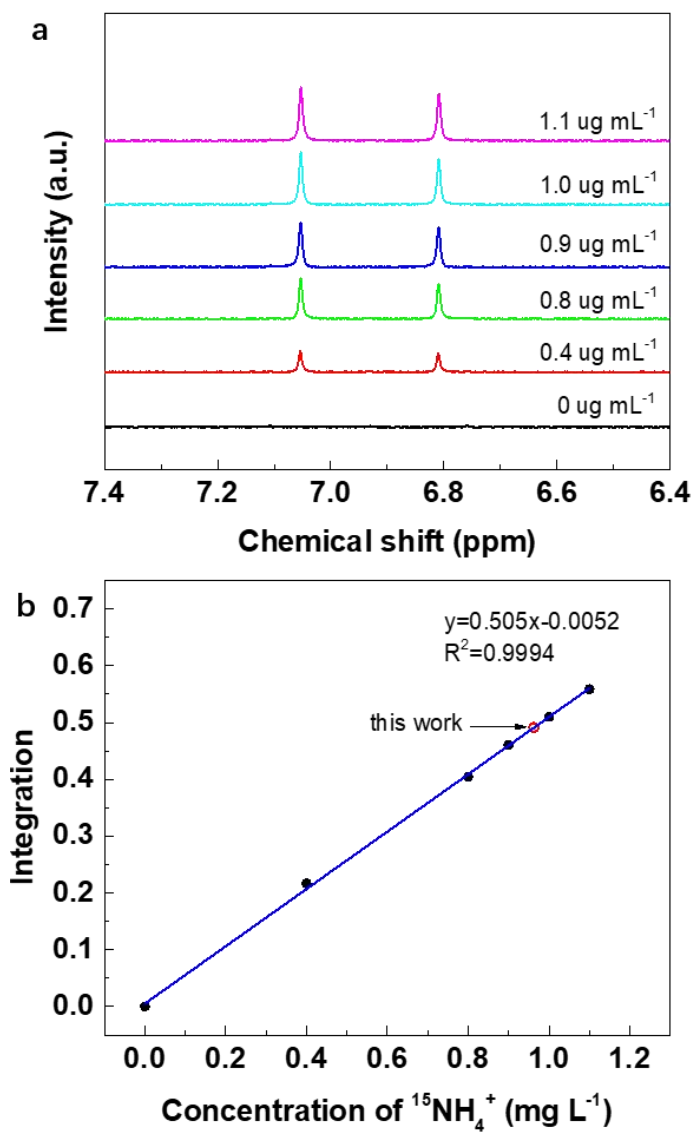

Figure S13. NMR spectra and calibration curve. (a) The $1 \mathrm{H}-\mathrm{NMR}$ spectra of standard ${ }^{15} \mathrm{NH}_{4}{ }^{+}$with a series of preset concentrations. (b) The calibration curve showing the correlation of ${ }^{15} \mathrm{NH}_{4}{ }^{+}$concentration with the integrated area of the $1 \mathrm{H}-\mathrm{NMR}$ peaks. The calibration curve showed a good linear dependence of the integrated area on ${ }^{15} \mathrm{NH}_{4}{ }^{+}$ concentration $\left(\mathrm{y}=0.505 \mathrm{x}-0.0052, \mathrm{R}^{2}=0.9994\right)$. The red circle indicated that the concentration of ${ }^{15} \mathrm{NH}_{4}{ }^{+}$was $0.97 \mathrm{mg} \mathrm{L}^{-1}$ after electrolysis at $-0.7 \mathrm{~V}$ vs. RHE for $1 \mathrm{~h}$ with ${ }^{15} \mathrm{~N}_{2}$ as the feeding gas. 

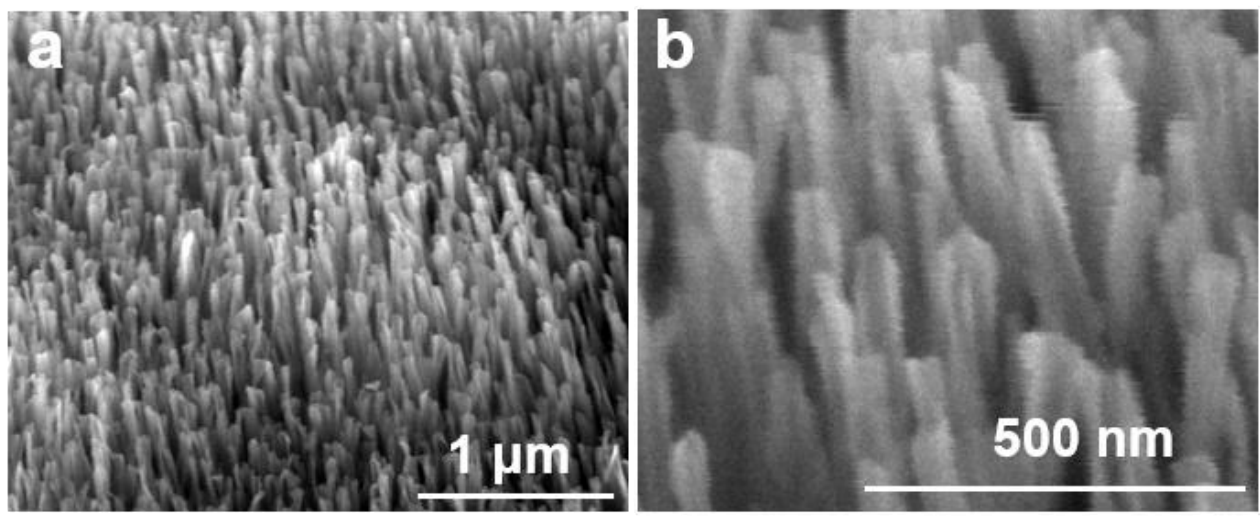

Figure S14. SEM images of $\mathbf{B N D}_{2}-\mathbf{N P} / \mathrm{Ti}$ electrode. (a) Low- and (b) high-magnification SEM images of $\mathrm{BND}_{2}-\mathrm{NP} / \mathrm{Ti}$ electrode obtained with an etching bias of $-150 \mathrm{~V}$. 

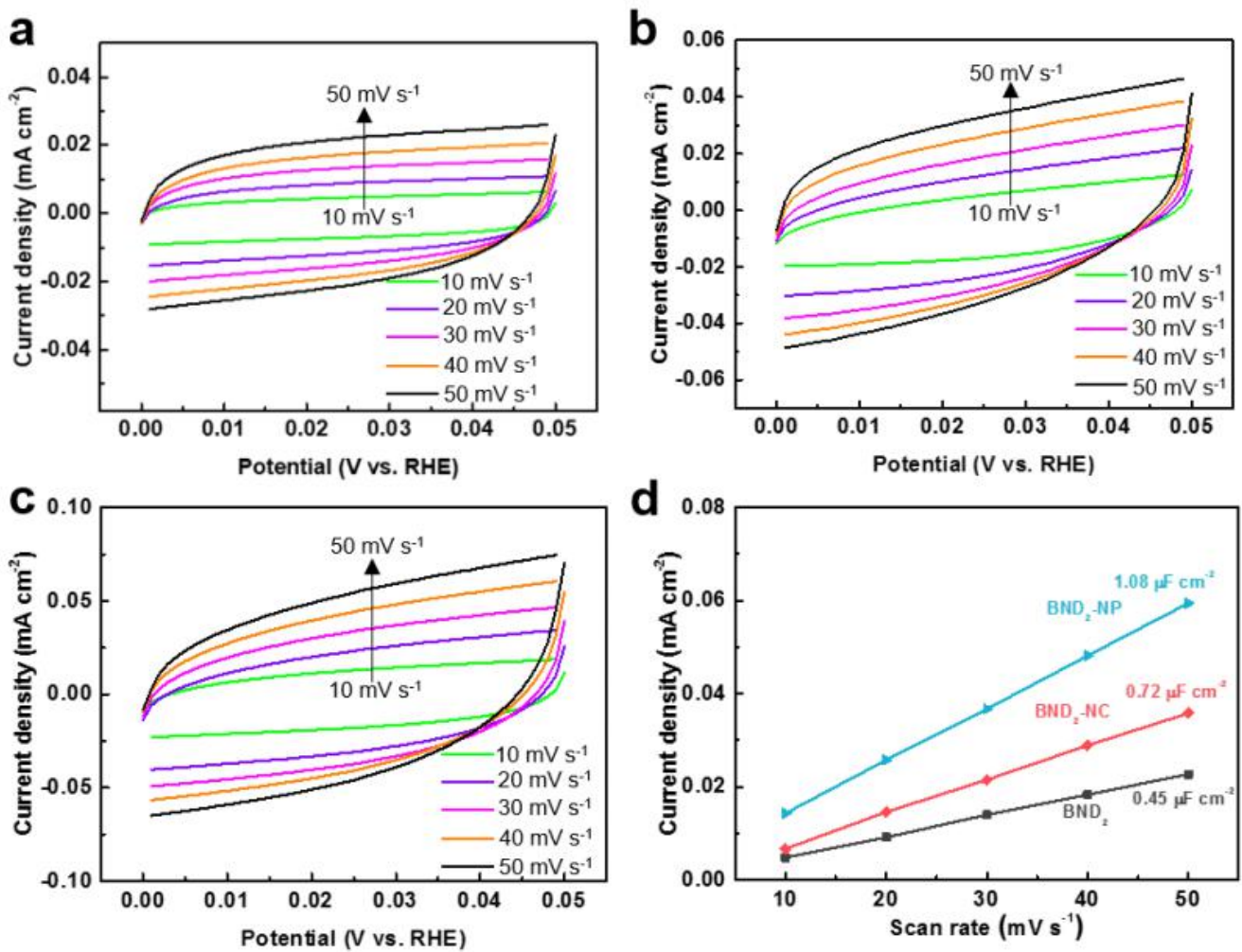

Figure S15. CV curves and the dependence of current density on the potential scan rate. CV curves of (a) $\mathrm{BND}_{2} / \mathrm{Ti}$, (b) $\mathrm{BND}_{2}-\mathrm{NC} / \mathrm{Ti}$ and (c) $\mathrm{BND}_{2}-\mathrm{NP} / \mathrm{Ti}$ electrodes recorded at different scan rates $\left(10 \sim 50 \mathrm{mV} \mathrm{s}^{-1}\right)$. (d) The dependence of current density on the potential scan rate obtained on these electrodes. 


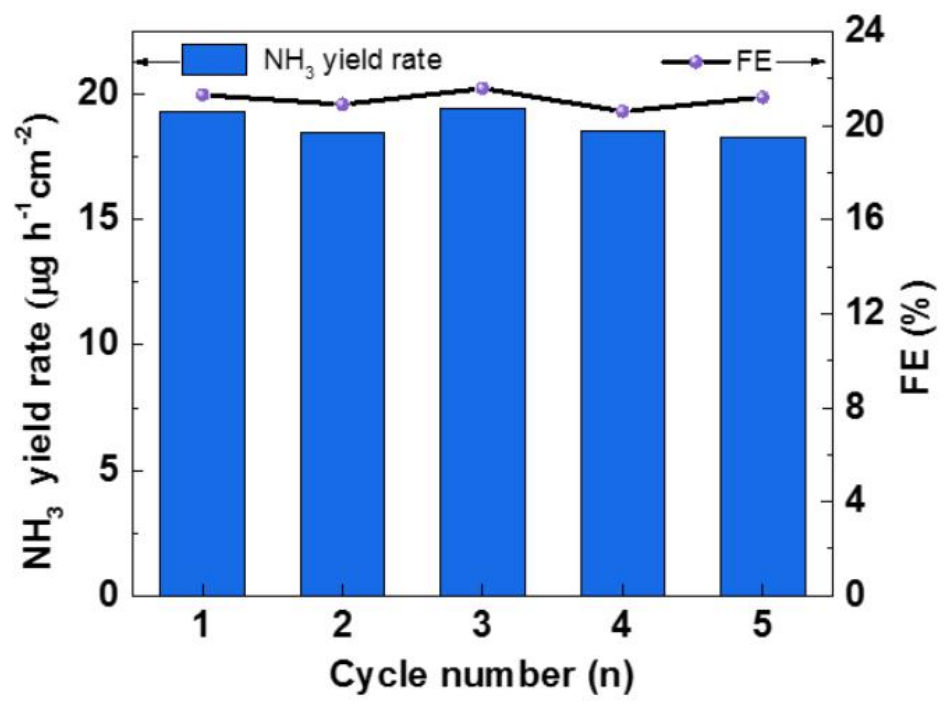

Figure S16. Cycling test results of $\mathrm{BND}_{2}-\mathrm{NC} / \mathrm{Ti}$ electrode after after 8-day NRR electrolysis. 

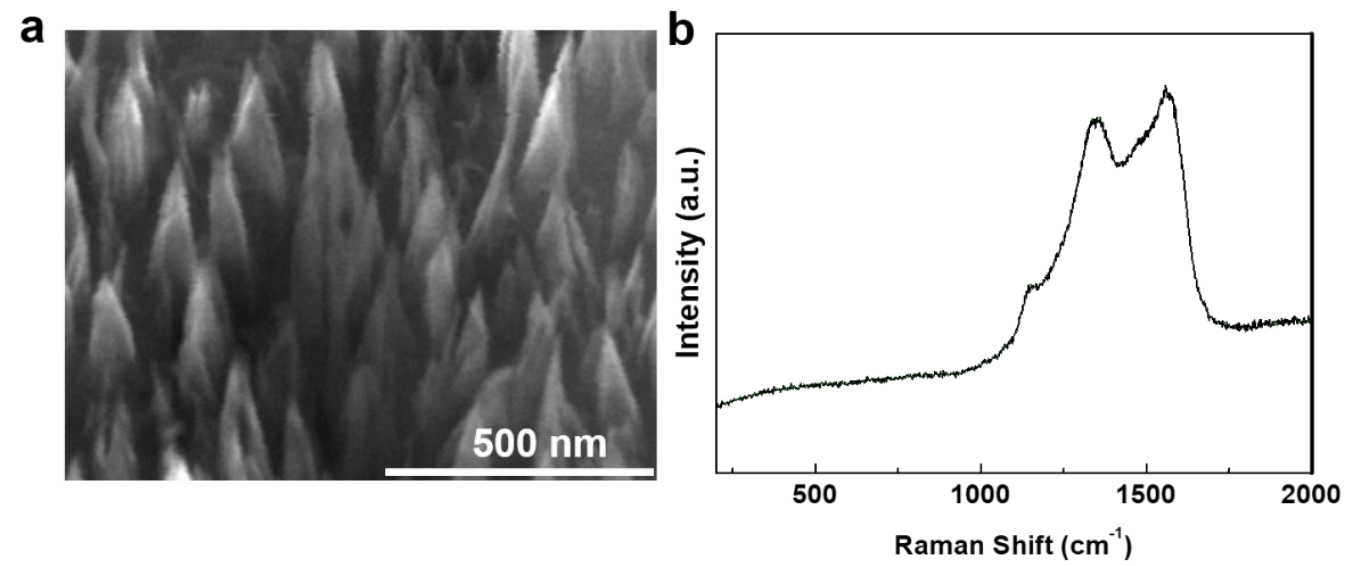

Figure S17. SEM image and Raman spectrum. (a) SEM image and (b) Raman spectrum of $\mathrm{BND}_{2}-\mathrm{NC} / \mathrm{Ti}$ after cycling tests at $-0.7 \mathrm{~V}$ vs. RHE. 
(a)
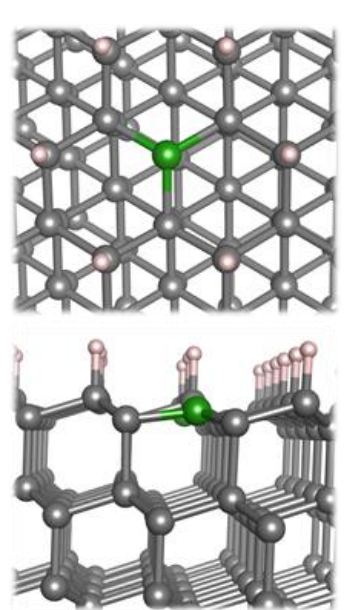

(b)
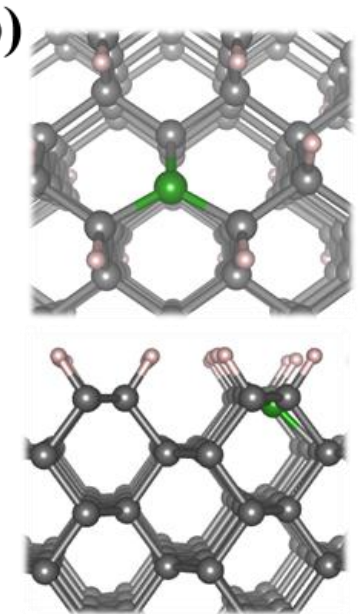

(c)
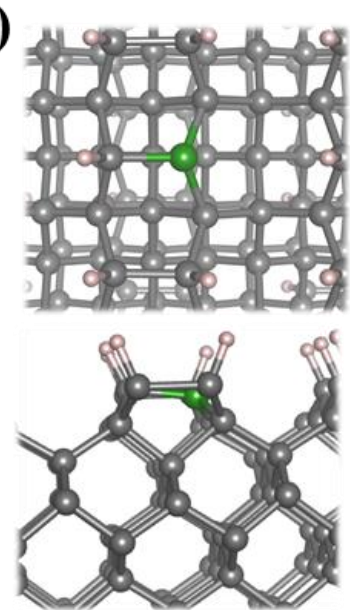

Figure S18. Top and side views of atomic structures of (a) (111), (b) (110), and (c) (100) diamond surfaces with substitutionally doped boron atoms. The grey, green and smaller pink balls denote C, $\mathrm{B}$ and $\mathrm{H}$ atoms, respectively. The dangling bonds of $\mathrm{sp}^{3} \mathrm{C}$ on these surfaces are energetically favorable to be passivated by hydrogen atoms in a reducing environment. Specifically, C-H bonds are vertically aligned on the (111) surface, while they are tilted on the (110) and (100) surfaces. In addition, the (100) surface undergoes reconstruction by tilting $\mathrm{C}-\mathrm{C}$ bonds to satisfy the valence of surface $\mathrm{sp}^{3} \mathrm{C}$. 

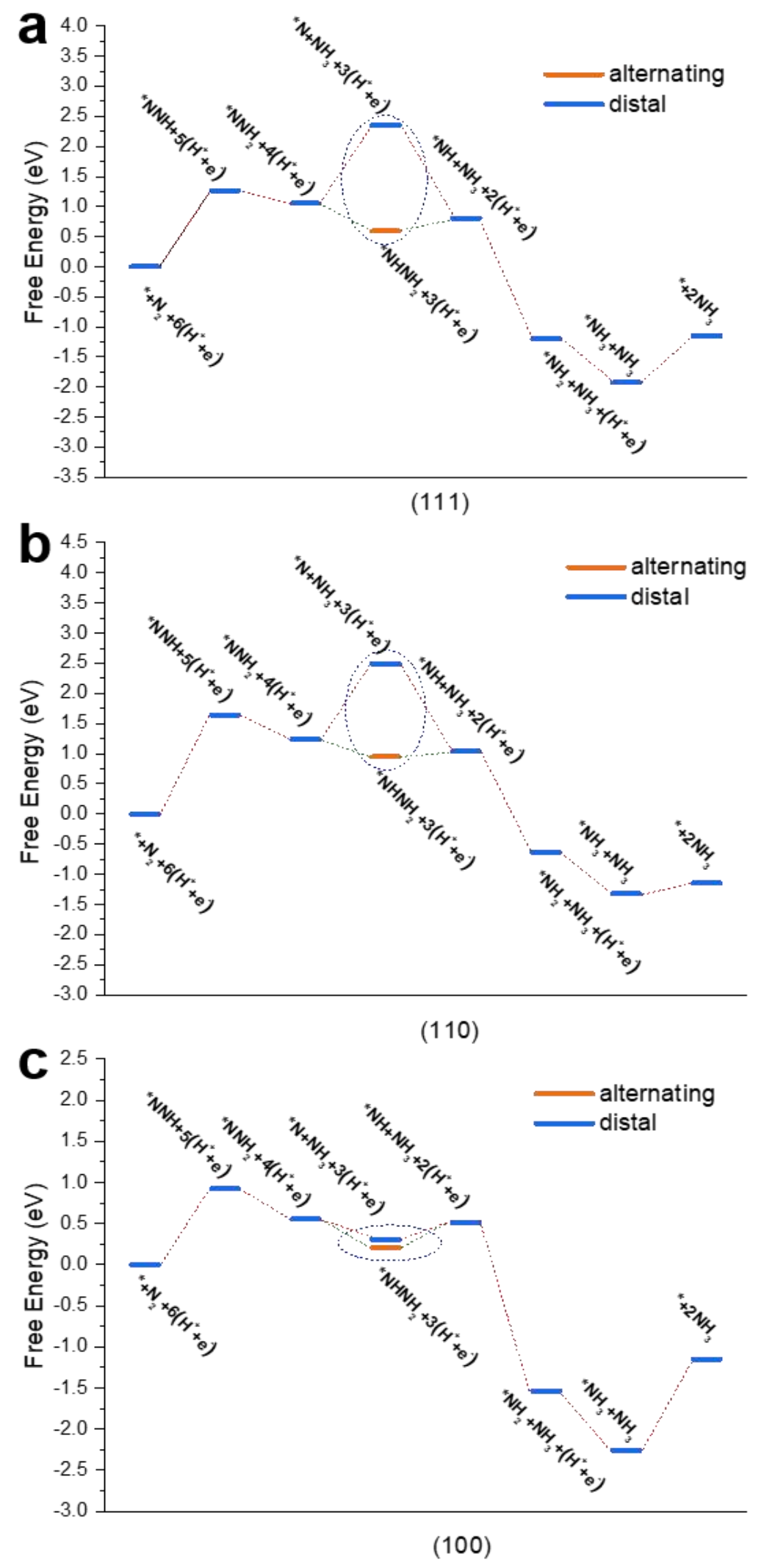

Figure S19. Free energy diagrams of NRR on boron-doped (a) (111), (b) (110), and (c) (100) surfaces through alternating and distal pathways. Breaking of the $\mathrm{N}-\mathrm{N}$ bonds in ${ }^{*} \mathrm{NNH}_{2}$ 
intermediates through distal pathway is energetically less favorable, especially on the (111) and (110) surfaces, owing to the limited amount of valence electrons of $\mathrm{B}$ sites to stabilize the dangling $\mathrm{N}$ atoms. 
Table S1. Summary of the performance of the representative metal-free electrocatalysts for $\mathrm{N}_{2}$ fixation at ambient conditions.

\begin{tabular}{|c|c|c|c|c|}
\hline Catalyst & Electrolyte & $\mathbf{V}_{\mathrm{NH}}{ }^{*}$ & $\mathbf{F E}$ & Ref. \\
\hline $\mathrm{BND}_{2}-\mathrm{NC}$ & $\begin{array}{c}0.05 \mathrm{M} \mathrm{H}_{2} \mathrm{SO}_{4}+0.2 \\
\mathrm{M} \mathrm{Li}_{2} \mathrm{SO}_{4}\end{array}$ & $19.1 \mu \mathrm{g} \mathrm{h}^{-1} \mathrm{~cm}^{-2}$ & $21.2 \%$ & This work \\
\hline $\mathrm{B}_{4} \mathrm{C}$ & $0.1 \mathrm{M} \mathrm{HCl}$ & $2.657 \mu \mathrm{g} \mathrm{h}^{-1} \mathrm{~cm}^{-2}$ & $15.95 \%$ & $\begin{array}{l}\text { Nat. Commun. 2018, } 9, \\
3485 .\end{array}$ \\
\hline B-graphene & $0.05 \mathrm{M} \mathrm{H}_{2} \mathrm{SO}_{4}$ & $9.8 \mu \mathrm{g} \mathrm{h}^{-1} \mathrm{~cm}^{-2}$ & $10.8 \%$ & Joule 2018, 2, 1610. \\
\hline $\begin{array}{c}\text { polymeric carbon } \\
\text { nitride }\end{array}$ & $0.1 \mathrm{M} \mathrm{HCl}$ & $16.18 \mu \mathrm{g} \mathrm{h}^{-1} \mathrm{~cm}^{-2}$ & $11.59 \%$ & $\begin{array}{l}\text { Angew. Chem. Int. Ed. } \\
\mathbf{2 0 1 8}, 57,10246 .\end{array}$ \\
\hline $\begin{array}{l}\text { N-doped carbon } \\
\text { nanospikes }\end{array}$ & $0.25 \mathrm{M} \mathrm{Li}_{2} \mathrm{SO}_{4}$ & $97.18 \mu \mathrm{g} \mathrm{h}^{-1} \mathrm{~cm}^{-2}$ & $11.56 \%$ & Sci. Adv. 2018, 4, 1700336 \\
\hline $\begin{array}{c}\text { nitrogen-doped } \\
\text { nanoporous carbon } \\
\text { membranes }\end{array}$ & $0.1 \mathrm{M} \mathrm{HCl}$ & $8 \mu \mathrm{g} \mathrm{h}^{-1} \mathrm{~cm}^{-2}$ & $5.2 \%$ & $\begin{array}{l}\text { Angew. Chem. Int. Ed. } \\
\text { 2018, 57, } 12360 .\end{array}$ \\
\hline $\mathrm{NPC}^{*}$ & $0.05 \mathrm{M} \mathrm{H}_{2} \mathrm{SO}_{4}$ & $14.28 \mu \mathrm{g} \mathrm{h}^{-1} \mathrm{~cm}^{-2}$ & $1.42 \%$ & ACS Catal. 2018, 8, 1186. \\
\hline Eex-COF/NC ${ }^{*}$ & $0.1 \mathrm{M} \mathrm{KOH}$ & $12.53 \mu \mathrm{g} \mathrm{h}^{-1} \mathrm{~cm}^{-2}$ & $45.43 \%$ & $\begin{array}{c}\text { Nat. Commun. 2019, } 10, \\
3898 .\end{array}$ \\
\hline $\mathrm{NPC}^{*}$ & $0.005 \mathrm{M} \mathrm{H}_{2} \mathrm{SO}_{4}$ & $22.2 \mu \mathrm{g} \mathrm{h}^{-1} \mathrm{~cm}^{-2}$ & $9.98 \%$ & $\begin{array}{c}\text { ACS Energy Lett. 2019, 4, } \\
377 .\end{array}$ \\
\hline
\end{tabular}

*: Eex-COF/NC: the eletrochemically excitated covalent organic frameworks (Eex-COFs) supported on nitrogen-doped carbon nanosheet (NC);

NPC: nitrogen-doped porous carbon;

$\mathrm{V}_{\mathrm{NH} 3}: \mathrm{NH}_{3}$ yield rate. 
Table S2. Summary of the performance of the representative metal-based electrocatalysts for electrocatalytic $\mathrm{N}_{2}$ fixation at ambient conditions.

\begin{tabular}{|c|c|c|c|c|}
\hline Catalyst & Electrolyte & $\mathbf{V}_{\mathrm{NH} 3}{ }^{*}$ & FE & Ref. \\
\hline $\mathrm{BND}_{2}-\mathrm{NC}$ & $\begin{array}{c}0.05 \mathrm{M} \mathrm{H}_{2} \mathrm{SO}_{4}+0.2 \\
\mathrm{M} \mathrm{Li}_{2} \mathrm{SO}_{4}\end{array}$ & $19.1 \mu \mathrm{g} \mathrm{h}^{-1} \mathrm{~cm}^{-2}$ & $21.2 \%$ & This work \\
\hline $\mathrm{Au} / \mathrm{CeO}_{\mathrm{x}}$ & $0.1 \mathrm{M} \mathrm{HCl}$ & $8.31 \mu \mathrm{g} \mathrm{h}^{-1} \mathrm{~cm}^{-2}$ & $7.79 \%$ & $\begin{array}{c}\text { Adv. Mater. 2017, } 29 \\
1700001 .\end{array}$ \\
\hline Au HNCs & $0.5 \mathrm{M} \mathrm{LiClO} 4$ & $3.90 \mu \mathrm{g} \mathrm{h}^{-1} \mathrm{~cm}^{-2}$ & $30.2 \%$ & $\begin{array}{c}\text { Nano Energy 2018, 49, } \\
316\end{array}$ \\
\hline Ru SAs/N-C & $0.05 \mathrm{M} \mathrm{H}_{2} \mathrm{SO}_{4}$ & $32.9 \mu \mathrm{g} \mathrm{h}^{-1} \mathrm{~cm}^{-2}$ & $29.6 \%$ & $\begin{array}{c}\text { Adv. Mater. 2018, } 30, \\
1803498 .\end{array}$ \\
\hline Mo nanofilm & $0.01 \mathrm{M} \mathrm{H}_{2} \mathrm{SO}_{4}$ & $1.89 \mu \mathrm{g} \mathrm{h}^{-1} \mathrm{~cm}^{-2}$ & $0.72 \%$ & $\begin{array}{c}\text { J. Mater. Chem. A 2017, } \\
\text { 5, } 18967 .\end{array}$ \\
\hline $\mathrm{Fe}_{2} \mathrm{O}_{3}-\mathrm{CNT}$ & $\mathrm{KHCO}_{3}$ & $0.22 \mu \mathrm{g} \mathrm{h}^{-1} \mathrm{~cm}^{-2}$ & $0.15 \%$ & $\begin{array}{c}\text { Angew. Chem., Int. Ed. } \\
\text { 2017, 56, } 2699 .\end{array}$ \\
\hline Bi NS & $0.1 \mathrm{M} \mathrm{Na}_{2} \mathrm{SO}_{4}$ & $2.54 \mu \mathrm{g} \mathrm{h}^{-1} \mathrm{~cm}^{-2}$ & $10.49 \%$ & ACS Catal. 2019, 9, 2902. \\
\hline $\mathrm{Bi}_{4} \mathrm{~V}_{2} \mathrm{O}_{11} / \mathrm{CeO}_{2}$ & $\mathrm{HCl}(\mathrm{pH} 1)$ & $46.42 \mu \mathrm{g} \mathrm{h}^{-1} \mathrm{~cm}^{-2}$ & $10.16 \%$ & $\begin{array}{c}\text { Angew. Chem. Int. Ed. } \\
\mathbf{2 0 1 8}, 57,6073 .\end{array}$ \\
\hline S-rich $\mathrm{MoS}_{2}$ nanosheets & $\begin{array}{l}0.1 \mathrm{M} \mathrm{Li}_{2} \mathrm{SO}_{4} \\
(\mathrm{pH} 3)\end{array}$ & $26.8 \mu \mathrm{g} \mathrm{h}^{-1} \mathrm{~cm}^{-2}$ & $9.8 \%$ & $\begin{array}{c}\text { Adv. Energy Mater. } 2019, \\
\text { 9, } 1803935 .\end{array}$ \\
\hline PEBCD $^{*}$ & $0.50 \mathrm{M} \mathrm{Li}_{2} \mathrm{SO}_{4}$ & $2.01 \mu \mathrm{g} \mathrm{h}^{-1} \mathrm{~cm}^{-2}$ & $1.71 \%$ & $\begin{array}{l}\text { J. Am. Chem. Soc. 2017, } \\
\text { 139, } 9771 .\end{array}$ \\
\hline $\mathrm{MoS}_{2}$ & $0.10 \mathrm{M} \mathrm{HCl}$ & $5.38 \mu \mathrm{g} \mathrm{h}^{-1} \mathrm{~cm}^{-2}$ & $1.17 \%$ & $\begin{array}{c}\text { Adv. Mater. 2018, 30 } \\
1800191 .\end{array}$ \\
\hline $\mathbf{N V}-\mathbf{W}_{\mathbf{2}} \mathbf{N}$ & $0.10 \mathrm{M} \mathrm{KOH}$ & $2.23 \mu \mathrm{g} \mathrm{h}^{-1} \mathrm{~cm}^{-2}$ & $11.67 \%$ & $\begin{array}{c}\text { Adv. Mater. 2019, 31, } \\
1902709 .\end{array}$ \\
\hline $\mathrm{Ti}_{3} \mathrm{C}_{2} \mathrm{~T}_{\mathrm{x}}$ MXene & $0.50 \mathrm{M} \mathrm{Li}_{2} \mathrm{SO}_{4}$ & $4.72 \mu \mathrm{g} \mathrm{h}^{-1} \mathrm{~cm}^{-2}$ & $4.62 \%$ & Joule, 2019, 3, 279. \\
\hline $\mathrm{OV}-\mathrm{Fe}_{2} \mathrm{O}_{3}{ }^{*}$ & $0.10 \mathrm{M} \mathrm{KOH}$ & $0.46 \mu \mathrm{g} \mathrm{h}^{-1} \mathrm{~cm}^{-2}$ & $6.04 \%$ & $\begin{array}{c}\text { Chem.Eur. J. 2018, 24, } \\
18494 .\end{array}$ \\
\hline $\mathbf{R u} / \mathbf{M o S}_{2}$ & $0.01 \mathrm{M} \mathrm{HCl}$ & $6.98 \mu \mathrm{g} \mathrm{h}^{-1} \mathrm{~cm}^{-2}$ & $17.6 \%$ & $\begin{array}{c}\text { ACS Energy Lett. 2019, } 4 \text {, } \\
430 .\end{array}$ \\
\hline $\mathrm{C} @ \mathrm{CoS} @ \mathrm{TiO}_{2}$ & $0.1 \mathrm{M} \mathrm{Na}_{2} \mathrm{SO}_{4}$ & $49.5 \mu \mathrm{g} \mathrm{h}^{-1} \mathrm{~cm}^{-2}$ & $28.6 \%$ & $\begin{array}{r}\text { Angew. Chem. Int. Ed. } \\
\text { 2019, 58, } 18903 .\end{array}$ \\
\hline $\mathrm{Ru} / \mathrm{TiO}_{2}$ & $0.10 \mathrm{M} \mathrm{KOH}$ & $2.11 \mu \mathrm{g} \mathrm{h}^{-1} \mathrm{~cm}^{-2}$ & $0.72 \%$ & $\begin{array}{l}\text { J. Energy Chem. 2019, } \\
\text { 39, } 144 .\end{array}$ \\
\hline
\end{tabular}

*: PEBCD: poly(N-ethyl-benzene-1,2,4,5-tetracarboxylic diimide);

OV: oxygen vacancy;

$\mathrm{V}_{\mathrm{NH} 3}: \mathrm{NH}_{3}$ yield rate. 


\section{References.}

1. Zhang W., Meng X., Chan C., Wu Y., Bello I., Lee S. Oriented single-crystal diamond cones and their arrays. Appl. Phys. Lett. 2003, 82, 2622-2624.

2. Yang Y., Yuen M.-F., Chen X., Xu S., Tang Y., Zhang W. Fabrication of arrays of high-aspect-ratio diamond nanoneedles via maskless ECR-assisted microwave plasma etching. CrystEngComm 2015, 17, 2791-2800.

3. Banerjee A., Bernoulli D., Zhang H., Yuen M.-F., Liu J., Dong J., Ding F., Lu J., Dao M., Zhang W., Lu Y., Suresh S. Ultralarge elastic deformation of nanoscale diamond. Science 2018, 360, 300-302.

4. Li L., Tang C., Yao D., Zheng Y., Qiao S.-Z. Electrochemical nitrogen reduction: identification and elimination of contamination in electrolyte. ACS Energy Lett. 2019, 4, 2111-2116.

5. Li J., Chen S., Quan F., Zhan G., Jia F., Ai Z., Zhang L. Accelerated dinitrogen electroreduction to ammonia via interfacial polarization triggered by single-atom protrusions. Chem 2020, 6, 885-901.

6. Wang Y., Shi M., Bao D., Meng F., Zhang Q., Zhou Y., Liu K., Zhang Y., Wang J., Chen Z. Generating defect-rich bismuth for enhancing the rate of nitrogen electroreduction to ammonia. Angew. Chem. Int. Ed. 2019, 58, 9464-9469.

7. Huang H., Li F., Xue Q., Zhang Y., Yin S., Chen Y. Salt-templated construction of ultrathin cobalt doped iron thiophosphite nanosheets toward electrochemical ammonia synthesis. Small 2019, 15, 1903500.

8. Zhou F., Azofra L. M., Ali M., Kar M., Simonov A. N., McDonnell-Worth C., Sun C., 
Zhang X., MacFarlane D. R. Electro-synthesis of ammonia from nitrogen at ambient temperature and pressure in ionic liquids. Energy Environ. Sci. 2017, 10, 2516-2520.

9. Kresse G., Furthmüller J. Efficiency of ab-initio total energy calculations for metals and semiconductors using a plane-wave basis set. Comput. Mater. Sci. 1996, 6, 15-50.

10. Blöchl P. E. Projector augmented-wave method. Phys. Rev. B 1994, 50, 17953.

11.Perdew J. P., Burke K., Ernzerhof M. Generalized gradient approximation made simple. Phys. Rev. Lett. 1996, 77, 3865.

12. Liu X., Jiao Y., Zheng Y., Jaroniec M., Qiao S.-Z. Building up a picture of the electrocatalytic nitrogen reduction activity of transition metal single-atom catalysts. J. Am. Chem. Soc. 2019, 141, 9664-9672.

13. Guo X., Gu J., Lin S., Zhang S., Chen Z., Huang S. Tackling the activity and selectivity challenges of electrocatalysts toward the nitrogen reduction reaction via atomically dispersed biatom catalysts. J. Am. Chem. Soc. 2020, 142, 5709-5721.

14. Zou Y., Yang Y., Zhou Y., Li Z., Yang H., He B., Bello I., Zhang W. Surface nanostructuring of boron-doped diamond films and their electrochemical performance. $J$. Nanosci. Nanotechnol. 2011, 11, 7914-7919.

15. Wang Y., Lau S., Tay B., Zhang X. Resonant Raman scattering studies of Fano-type interference in boron doped diamond. J. Appl. Phys. 2002, 92, 7253-7256. 